\title{
Developing the Concept of Perceived Competence among Students with Learning Disabilities
}

\author{
Ahmad M. J. O. AL Fawair ${ }^{1}$, Jamal M. S. AL Khateeb ${ }^{2} \&$ Yazan Abdel Aziz Semreen AL-Wreikat $^{3}$ \\ ${ }^{1}$ School of Educational Studies, Universiti Sains Malaysia, Penang, Malaysia \\ ${ }^{2}$ Faculty of Education, University of Jordan, Amman, Jordan \\ ${ }^{3}$ Educational Research and Evaluation Department, Asian EFL Academy, Penang, Malaysia \\ Correspondence: Ahmad M. J. O. AL Fawair, School of Educatioal Studies, Universiti Sains Malaysia, Penang, \\ Malaysia. Tel: 60-125-494-965. E-mail: Ahmadseafaory@yahoo.com
}

Received: January 16, 2012

Accepted: March 29, $2012 \quad$ Online Published: September 14, 2012

doi:10.5539/jedp.v2n2p127

URL: http://dx.doi.org/10.5539/jedp.v2n2p127

\begin{abstract}
The current research is designed to examine the relationship between a training program designed for students with learning disabilities and their perceived competence. The need for such endeavor must be accorded due attention in order to create a comprehensive policy reform that takes into account the different dimensions of effectual reform. The study declares the need for providing a clear insight into the obstacles faced by Jordanian students, especially those in the rural areas, who are continually hampered by learning disabilities. In an attempt to answer the research questions, the "Perceived Competence Scale for Children" (Harter, 1982) was used as the main tool in the current study. Moreover, the study sample consisted of 26 fourth-grade students with learning disabilities who joined the resource rooms of the Ministry of Education in the Jerash district of Jordan. Findings of the study indicated the presence of significant statistical differences between the experimental group that underwent the training program and the control group that was not exposed to it.
\end{abstract}

Keywords: perceived competence, learning disabilities, Jordan, effectiveness

\section{Introduction}

Jordan is currently witnessing a rising interest in the field of special education, with unique focus on children with learning disabilities. Researchers have been urged to study the factors affecting such students and highlight the means by which appropriate teaching methodologies can be designed and implemented. The problem is reflected in the children's learning abilities, creating barriers in their learning process. Barriers include the children's perceived competence, which was low, thus negatively affecting their achievement level and social attitude with teachers, peers, and parents (Elbaum and Vaughn, 2003).

Several studies conducted worldwide illustrate that children with learning disabilities often develop negative concept of themselves. They do not feel the satisfaction of those around them in what they are doing; they fail both academically and socially, frequently leading to frustration, disappointment, and ultimately low self-concept. Furthermore, they lack essential skills and abilities such as motor-visual synergy, and experience a form of impairment in attention and memory. They are subjected to disturbances in thinking as well as difficulty in solving problems and understanding concepts.

Learning disabilities experienced by children consume a significant part of their mental and emotional energy, which in turn causes emotional disturbances or consensual effect on overall personality. These may trigger poor compatibility in personal, emotional, and social aspects, with children becoming more susceptible to introversion, depression, withdrawal, and the formation of negative self-image (Zayat, 1998). Numerous research studies have confirmed a connection between perceived competence in children and their perceived visible behavior and academic performance (Lapin and Green, 1980). In further probing the problem, Lecky demonstrates that low achievement may be attributed to the fact that the child may fail to regard himself as an educated person. Moreover, low achievers were observed to view themselves in a negative manner while high achievers maintained a positive view of themselves (Shown, 2004). In other words, children with low self-confidence are trapped in the belief that they have little or no value, affecting their motivation, behavior, and general outlook on life (Scheffer and Mlman, 2001). 
Other researchers (AL-Wkfee, 2000) emphasize that students with learning disabilities are characterized by their adoption of low and negative self-concept; they often lack self-reliance, speak about themselves in a frivolous manner, and even demean themselves because of repeated failure. Moreover, Lerner (2000) argues that students with learning disabilities are usually fearful, resulting from prolonged lack of encouragement, frustration, despair, sense of rejection and failure, and loss of hope for the future. All these negatively affect the efficiency perceived in the student both at school and at home.

AL-Wkfee (1998) stresses a crucial need for a program that seeks to develop students' perceived competence, especially those with learning disabilities who continue to deal with various issues and problems that are not addressed and treated in a scientific manner. It is important to design a program that focuses on the dimensions of their personality, needs, interests, preferences, and unique characteristics. Hence, this study has created a training program aimed at enhancing and developing perceived competence among students with learning disabilities.

\section{Research Objectives}

This study examines the effectiveness of a training program on an experimental group to enhance perceived competence. Its intent is to provide insights into the role of special programs in upgrading students' abilities and achievement level, especially those with learning disabilities. Specifically, the objectives of this research are as follows:

- To clarify the extent to which the developed program will influence the concept of perceived competence among students with learning disabilities

- To identify other factors that appear to affect the concept of perceived competence among students with learning disabilities

To achieve the above research objectives, the following research questions were formulated:

- To what extent does the developed program influence the concept of perceived competence among students with learning disabilities?

- What are the other factors that appear to affect the concept of perceived competence among students with learning disabilities?

\section{Review of Literature}

A number terms overlap in the attempt to define perceived competence: self-acceptance, self-assertion, self-fulfillment, self-awareness, self-image, and so on (Bahadir, 1983). The term itself - perceived competence represents two sides of a coin, indicating that the conscious part is perceived by an entity of the human personality that can be seen and identified. The terms self-concept, self-esteem, and perceived competence are synonymous and cannot be separated (Harter, 1982).

The multi-dimensionality of self-esteem creates many disabilities in its measurement. Therefore, it is considerably more prudent to study the individual experience categories. The experience category, which may hold the most promise for physical educators and their claim to increased self-esteem, may lie within perceived physical competence. Perceived adequacy of the important dimensions of human personality has a significant impact on the individual's behavior and actions, as perceived competence plays a key role in guiding and creating behavior. A student who views himself as intelligent, studious, and hard-working tends to act on this idea (Hussein, 1987).

Perceived physical competence is defined as one's overall perception of personal physical abilities. It is important to note that one's perceived physical competence is a subjective view of physical abilities, and these perceptions may or may not coincide with the actual ability. Perceived physical competence is considered to be the more global construct compared with physical self-efficacy. Therefore, it is considered to be people's overall perceptions of their general physical abilities in accomplishing physical tasks. In most psychological theories, self-concept is an important concept in the study of personality, perceived skills, and psychological adjustment.

In the psychological aspect, the term "self" is used in two ways. The first - "self-appointed" - refers to the individual and his feelings, while the second refers to a process composed of a set of elements such as thinking, memory, and cognition (Zahran, 2003). Moreover, self-efficacy is defined as situation-specific self-confidence, indicating the strength and level at which one believes one can successfully perform a skill or task (Bandura, 1977). Therefore, one's self-efficacy toward a specific task is affected by the contextual variables surrounding the task, as well as one's perceptions of one's ability to cope with these factors. Researchers have achieved moderate success in measuring the strength and level of self-efficacy (Bandura, 1986; Clark and Nelson, 1990; McAuley and Gill, 1983). These influences on self-efficacy are listed in order of their significant contributions to how people perceive 
their ability on physical tasks. Thus, performance attainment is the single most powerful influence on one's perceived physical competence.

Variables that affect self-efficacy contribute to the complexity of utilizing efficacy judgments to motivate school-aged children. As detailed in an earlier discussion, the social cognitive theory posits that people are not driven by inner forces (autonomous) or controlled by external stimuli (mechanical), but are shaped by a model of triadic reciprocity in which behavior, cognitive factors, and the environment interact (emergent interactive agency) (Bandura, 1989, p. 1175). People's belief in their capability to exercise control over these factors determines their "self-efficacy" toward a task.

The issue then becomes how people judge their capabilities and how these efficacy judgments affect their motivation and behavior. Each person's model of triadic reciprocity is different; therefore, the variables affecting one 's self-efficacy may operate in a manner that is not homogeneous in its effect.

According to literature, social and cultural influences are the variables that exhibit powerful effects on self-efficacy. For example, gender may play a role in the development of perceptions of physical competence in the American society (Lirgg, 1992; Whitehead and Corbin, 1991). Perceived physical competence of males is generally higher than that of females, and this different situation may be attributed to social and cultural influences (Pate, Long and Heath, 1994). The issue of utilizing self-perception of efficacy to motivate school-aged children is evidently highly complex. However, the question remains: What benefit, if any, would further knowledge of self-efficacy and perceived competence provide to educators? The impact of research on self-efficacy for educators - specifically physical educators - would appear to center around what motivates the following:

1) An individuals' choice of activity or task

2) The amount of effort placed on a task

3) How long one will persist in the face of failure

\section{Methods}

A self-report instrument, "Perceived Competence Scale for Children" (Harter, 1982), was used as the main tool in the current study. The study sample consisted of 26 fourth-grade students (13 male and 13 female) with learning disabilities who joined the resource rooms in the Ministry of Education in the Jerash District. The samples were distributed in eight schools. Table 1 illustrates the distribution of the study samples according to school gender and number.

Table 1. Means and standard deviations of the two groups used for the study

\begin{tabular}{|c|c|c|c|c|}
\hline \multirow{2}{*}{ Group } & & \multicolumn{2}{|c|}{ Gender } & \multirow[b]{2}{*}{ Total } \\
\hline & & Females & Males & \\
\hline \multirow{2}{*}{ Control } & Mean & 57.095 & 55.134 & 56.115 \\
\hline & Standard deviation & 1.427 & 1.419 & 1.007 \\
\hline \multirow{2}{*}{ Experimental } & Mean & 84.617 & 84.692 & 84.655 \\
\hline & Standard deviation & 1.434 & 1.419 & 1.007 \\
\hline \multirow{2}{*}{ Total } & Mean & 70.856 & 69.913 & \\
\hline & Standard deviation & 1.003 & 1.003 & \\
\hline
\end{tabular}

Table 2. Sample of the study

\begin{tabular}{|c|c|c|c|c|c|}
\hline \multicolumn{3}{|l|}{ Experimental Group } & \multicolumn{3}{|l|}{ Control Group } \\
\hline School & Gender & $\begin{array}{l}\text { Number of } \\
\text { Students }\end{array}$ & School & Gender & $\begin{array}{l}\text { Number of } \\
\text { Students }\end{array}$ \\
\hline $\begin{array}{l}\text { Kafkafa } \\
\text { Primary School }\end{array}$ & Females & 6 & Sakeb Basic School & Males & 8 \\
\hline $\begin{array}{l}\text { Talat AL-Roz } \\
\text { Secondary School }\end{array}$ & Females & 5 & $\begin{array}{l}\text { AL-Mastaba Secondary } \\
\text { School }\end{array}$ & Females & 9 \\
\hline Soof basic school & Males & 8 & $\begin{array}{l}\text { Amneh Binti Wahb } \\
\text { Basic School }\end{array}$ & Females & 4 \\
\hline $\begin{array}{l}\text { Khafer Khal Basic } \\
\text { School }\end{array}$ & $\begin{array}{l}\text { Males and } \\
\text { females }\end{array}$ & $\begin{array}{l}5 \\
2\end{array}$ & $\begin{array}{l}\text { Marsaa Secondary } \\
\text { School }\end{array}$ & Males & 5 \\
\hline Total & & 26 & Total & & 26 \\
\hline
\end{tabular}


To achieve the objectives and answer the research questions, the study found that the best tool was the "Perceived Competence Scale" developed by Harter (1982). The instrument was modified to cope with the Jordanian environment and the unique societal traits. This step was carried out to insure the suitability of the instrument (Sheikah, 1993). The scale constitutes four main dimensions: social competence, cognitive competence, physical competence, and general self-worth.

\section{Findings and Discussion}

The purpose of this study was to identify the effectiveness of the training program and its impact on perceived competence among students with learning disabilities. In light of this, one of the crucial purposes of this study was to examine other factors that may affect students' perceived competence, especially those experiencing learning disabilities.

The results reveal the existence of differences in the adjusted averages for the dimensional testing in favor of the experimental group. Table 1 shows the means and standard deviations of the two groups used for the study. The study was able to verify this hypothesis through analysis of covariance bilateral. Results showed statistically significant differences in the dimensional scale; it preserved the variable efficiency perceived in children, in favor of the experimental group (84.655).

There were several findings based on the obtained data. Improvement in the concept of perceived adequacy as a whole, thinking and social adequacy, and physical adequacy in the experimental group may be due to the nature of the sessions included in the training program. This was first initiated with the aim of teaching students to improve their self-understanding through awareness of a realistic self-image and interaction with others. They were trained on self-reliance by developing independence and motor skills, and on the use of positive language to enhance their self-statement and achieve self-reinforcement. Moreover, the sessions addressed ways by which the individual can achieve successful interaction with others by offering gratitude and appreciation. Hence, student participation in the program was observed to help improve their understanding of self-perception and increased their self-confidence, abilities, skills, and sense of success.

Various training strategies were employed, such as social reinforcement, modeling, feedback, issuance of instructions, role play, and homework; these are considered to be among of the most effective methods identified in previous copious educational literature. The training program is marked by several positive features, including precise data and clear and simple language, which can assist teachers in applying the program. The program is flexible, easy to implement, and low cost. Therefore, it is easy for any teacher to provide tools funded by the school.

Teachers in charge of resources were asked to re-apply what has been accomplished in the activities and exercises in each session after two or three days of running each session. This procedure could increase the program's effectiveness and thus improve the concept of adequacy perceived among students with learning disabilities.

The results of the current study are in line with the findings of Elbaum and Vaughn (2003), whose study was aimed at determining the effectiveness of certain interventions represented in the development of children's skills in the academic sphere. The said study examined intervention guidelines (i.e., correct misconceptions and weakening self-defeating ideas) and explored physical interference and cognitive intervention in the development of the concept of perceived competence among students with learning disabilities. It found that students with learning disabilities subjected to the training program (intervention) exhibited statistically significant improvement in self-concept. Moreover, students with high level of academic achievement possessed enhanced self-esteem. These confirmed the findings of the current study, that such diverse programs provide the children with a wealth of opportunities for social interaction and awareness of the physical ability they possess, which is aimed at modifying the perspectives of individuals and correcting misconceived ideas that will be applied within a specific organized program targeted to increase the level of self-concept among students with learning disabilities.

Moreover, the current study is in line with the study conducted by AL-Smadi (2003), which found significant statistical differences due to self-concept, competence, and social and motor skills in favor of the experimental group. However, the study of AL-Smadi did not determine whether there are differences between the experimental groups due to race.

The results of the present study likewise affirm the findings of Omizo (1985), which indicated no statistically significant differences between the control and experimental groups with respect to the concept of self-pre-testing. Moreover, there are differences in statistical significance due to the self-concept between the control and experimental groups during post-testing. However, Omizo's study (1985) was aimed at determining the effect of collective guidance sessions (emotional, rational) on the concept of self and control center for children with 
learning disabilities.

The results of this study likewise support those of Dewlin's research (1991), which indicated significant statistical deference for the exercise of physical fitness and its impact on the development of self-concept. The training program in the current study contained sessions targeted at developing several motor skills in children through certain sports activities. Dewlin's study was aimed at assessing the developmental impact of a two-month physical fitness training program on changes in self-concept. The effectiveness of the program was a result of the willingness of school administrators to implement it throughout the school year, with the target of increasing the aspired benefits for the largest possible number of students with learning disabilities. Feedback from a group of students revealed a demand for more sessions to be held on a daily basis without interruption, confirming the effectiveness of the training program.

\section{Recommendations}

Pre-obtained results indicated the effectiveness of the training program in the development of the concept of perceived competence and development among students with learning disabilities. The most salient recommendations that require further exploration are as follows:

1) Conduct further research on the impact of the training program on different samples.

2) Conduct further research on the impact of a training program on self-concept in the category of learning disabilities and its relationship to variables such as the classroom level.

3) Develop in-service training courses for teachers to introduce to them the importance of the concept of perceived competence.

\section{References}

Elbaum, B., \& Vaughn, S. (2003). Self-concept and students with learning disabilities. In H. L. Swanson, K. R. Harris, \& S. Graham (Eds.), Handbook of learning disabilities (pp. 229-241). New York: The Guilford Press.

Harter, S. (1982). The Perceived Competence Scale for Children. Child Development, 53(1), 87-97. http://dx.doi.org/10.2307/1129640

Amerikaner, M., \& Summerlin, M. (1982). Group Counseling with Learning Disabled Children: Effects of Social skills and Relaxation Training on Self-Concept and Classroom Behavior. Journal of Learning Disabilities, 15(6), 340-343. http://dx.doi.org/10.1177/002221948201500607

Barksdale, L. S. (1972). Building Self-Esteem. Los- Angeles: Crenhaw Boulevard.

Bandura, A. (1989). Social cognitive theory. In E. Barnouw (Ed.), International encyclopedia of communications (pp. 92-96). New York: Oxford University Press.

Bandura, A. (1986). The explanatory and predictive scope of self-efficacy theory. Journal of Clinical and Social Psychology, 4, 359-373. http://dx.doi.org/10.1521/jscp.1986.4.3.359

Beltempo, J., \& Achille, P, A. (1990). The effect of special class placement on the self-concept of children with learning disabilities. Child Study Journal, 20(2), 81-104.

Bossing, A., \& Sassen, E. (1980). Building Positive Self Concept in Fourth Grade Students. US Department of Education.

Brigham, J. (1986). Social Psychology. Boston: Little Brown Co.

Burns, R. B. (1981). The Self-concept Theory Measurement, Development and Behavior. New York: Long man.

Campbel, P. C. (1990). An investigation of the self-concept and locus of control of specific learning- disabled students. Doctoral dissertation, University of detta state, Dissertation Abstracts International. 4 (1192).

Clark, V., \& Nelson, W. M. (1990). Negative expectations and selfevaluation in dysphoria. Journal of Youth and Adolescence, 19, 57-61. http://dx.doi.org/10.1007/BF01539445

Coleman, J. (1980). friendship and thepeer group in adolescence. In J. Adelson (Ed.), Hand book of adolescent psychology (pp. 408-432). New York: Wiley.

Dewlin, R. F. (1991). Self-concept changes in physically disabled adult men following eight weeks of physical fitness training, dissertation. Abstract international, 2(465).

Dyson, L. (2003). Children with Learning Disabilities within the Family Context: A Comparison with Siblings in Global Self-Concept, Academic Self-Perception, and Social Competence. Learning Disabilities Research \& 
Practice, 18(1), 1-9. http://dx.doi.org/10.1111/1540-5826.00053

Elbaum, B. (2002). The Self-Concept of Students with Learning Disabilities: A Meta-Analysis of Comparisons Across Different Placements. Learning Disabilities Research \& Practice, 17(4), 216-227. http://dx.doi.org/10.1111/1540-5826.00047

Elbaum, B., \& Vaughn, S. (2003). For which Students with Learning Disabilities Are Self-Concept Interventions Effective? Journal of Learning Disabilities, 36(2), 101-109. http://dx.doi.org/10.1177/002221940303600203

Gresham, F, M. (1984). Self Efficacy Diffrences among Midly Handicapped. Gifted and Non Handicapped Students. Journal of Special Education, 22(2), 231-239. http://dx.doi.org/10.1177/002246698802200208

Halmhaber, N. (1989). Competence, Control and Coping Strategies in Learning Disabled, Physically Impaired, and Requabar Education Students. Dissertation Abstract international, 5(11), 138.

Harrey, D., \& Greenway, F. (1984). The self-concept of physically handicapped children and their non handicapped siblings. An empirical investigation. Journal of Child Psychology and Psychiatry, 25(2), 284-273.

Harter, S. (1982). The Perceived Competence Scale for Children. Child Development, 53, 87-97. http://dx.doi.org/10.2307/1129640

Hergenhahn, B. R. (1980). An Introduction to Theories of Personality. Hamline University, Prentice-Hall, Englewood Cliffs.

Hosley, M., \& Hooper, C. (1987). Self-Concept and motor performance of children with learning disabilities. Perceptual and Motor skills, 87(3), 859-863. http://dx.doi.org/10.2466/pms.1998.87.3.859

Hurlock, E. P. (1974). Children Development. Mc Graw: Hill Book Company, N, Y.

Johnston, C., \& Kenneth, E. (2003). The Impact of Disability on Children's Self-Concept: The Implication for Theory Building. Retreived from http://www.aare.edu.au/qqpap/joh 99515.htm

Jones, J. (1983). An Analysis of the Self concept of Handicapped Students ages 10-13 Compared to Non handicapped Students. Dissertation Abstract International, 50(11), 137.

Karg, B., \& Dunnick. (1988). A Methodological Study of the Self Concept of Third Grade System Identified Gifted and Learning Handicapped Children. Dissertation Abstract International, 49(9), 188.

Klamm, K. (1990). An Analysis of Academic Performance, Self concept, Social Integration, Adaptive Behavior, and Consumer Satisfaction, in an Elementary Level Class within a class Alternative Service Delivery Model for students with Learning Disabilities. Dissertation Abstracts International, 51(12), 150.

Leahy, R. L. (1985). The Development of the Self. New York: Hofstra University Academic Press.

Lerner, J. W. (2000). Children with learning disabilities. Boston: Houghton Mifflin.

Lewandowski, L., \& Arcanglo, K. (1994). The social adjustment and self-concept of adults with learning $\begin{array}{lllll}\text { disabilities. } & \text { Journal of }\end{array}$ http://dx.doi.org/10.1177/002221949402700909

McAuley, E., \& Gill, D. (1983). Reliability and validity of the physical selfefficacy scale in a competitive sport setting. Journal of Sport Psychology, 5, 410-418.

Mocandless, B. (1977). Child Behavior and Development (3rd ed.). Holt, Rinehartand winston, Inc.

Montgomery, M. (1994). self-concept and children with learning disabilities: observer-child concordance across context-dependent domains. Journal of Learning Disabilities, 27(4), 254-263. http://dx.doi.org/10.1177/002221949402700909

Mulcahy, R. (1990). Perceived Competence, Self concept, and locus of Control for High Ability Students as a Compared to Average and Learning Disabled Students. Canadin Journal of Special Education, 6(1), 42-49.

Omizo, M. (1985). The effects of rational emotive education groups on self-concept and locus of control among learning disabled children. The Exceptional child, 32(1), 13-19. http://dx.doi.org/10.1080/0156655850320103

Reber, A. (1995). Dictionary of Psychology (2nd ed.). Pengin, Book England.

Robinson, G. (2003). Do Students with Learning Disability have A Low Self-Concept? Retrieved from http://www.exceptionalkids.com.au/education/self_concept.htm. 
Schunk, D. (2000). Learning Theories, an education perspective. New Jersey: Prentice Hall.

Shavelson, R., \& Bolus, R. (1982). Self-concept: the interplay of theory and methods. Journal of Educational Psychology, 74(1), 3-17. http://dx.doi.org/10.1037/0022-0663.74.1.3

Thomas, L. F., \& Harri - Augstein, E. (1985). Self-Organized Learning. London: Routldge \& Keganpaul. 